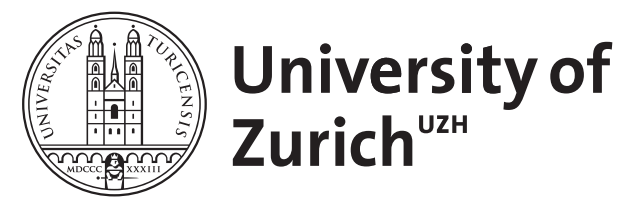

\title{
Gleaning: old name, new practice
}

Diković, Jovana

\begin{abstract}
The practice of gleaning is linked to the centuries-old custom embedded in the customary laws of many people, according to which the master of the land holds the right to allow the poor to follow harvesters in the field and to gather and glean the fallen spears of grain. In this article, the new meaning of the practice of gleaning is analyzed by using an example of one Serbian village in Vojvodina province, Gaj, which is still predominately agricultural. In a strict sense, the name of the old practice is kept, but the essence of the practice itself and its symbolism have changed radically. In previous times, the term "gleaning" referred to the reciprocal social, economic and political relationship between the poor and the landowner. Today, in the context of the village of Gaj, it is mostly used as a euphemism for field theft. The article analyzes this gradual shift in diachronic and social-anthropological perspectives, aiming to depict and explain crucial changes in informal and formal institutions that have contributed to this current understanding of gleaning.
\end{abstract}

DOI: https://doi.org/10.1080/07329113.2016.1165501

Posted at the Zurich Open Repository and Archive, University of Zurich

ZORA URL: https://doi.org/10.5167/uzh-134419

Journal Article

Accepted Version

Originally published at:

Diković, Jovana (2016). Gleaning: old name, new practice. Journal of Legal Pluralism and Unofficial Law, 48(2):302-321.

DOI: https://doi.org/10.1080/07329113.2016.1165501 


\title{
Jovana Dikovic
}

$\mathrm{PhD}$ candidate

Department of Social and Cultural Anthropology

University of Zurich

Schaufelbergerstrasse 55, 8055, Zurich, Switzerland

Mobile number: +41798870396

E-mail: jovana.dikovic@uzh.ch

\section{Gleaning: Old Name, New Practice}

\begin{abstract}
The practice of gleaning is linked to the centuries-old custom embedded in the customary laws of many peoples, according to which the master of the land holds the right to allow the poor to follow reapers in the field and to gather and glean the fallen spears of grain. In this paper, the new meaning of the practice of gleaning is analyzed by using an example of one Serbian village in Vojvodina province, Gaj, which is still predominately agricultural. In a strict sense, the name of the old practice is kept, but the essence of the practice itself and its symbolism have changed radically. In previous times, the term 'gleaning' referred to the reciprocal social, economic and political relationship between the poor and the landowner. Today, in the context of the village of Gaj, it is mostly used as a euphemism for field theft. The paper analyzes this gradual shift in diachronic and social-anthropological perspectives, aiming to depict and explain crucial changes in informal and formal institutions that have contributed to this current understanding of gleaning.
\end{abstract}

Keywords: gleaning, customary law, informal welfare, field theft, Roma, Vojvodina province (Serbia).

\section{Introduction}

Gleaning is linked to the centuries-old custom embedded in the customary laws of many peoples according to which the master of the land allows the poor to follow reapers in the field and to gather and glean the fallen spears of grain. One of the earliest agricultural laws of the Hebrews, described in the Old Testament, illustrates how the generosity of the master determined the amount of gleaned grains (The Story of Ruth 2:2-23). This early form of welfare for the needy is vastly widespread. In some places the old form of the custom is kept and involves the relationship between the landowner and the poor, while in other places different fate-based groups glean and redistribute leftover crops as part of their religious calling. Gleaning has also gained political and engaging connotations, particularly alongside the global development of capitalism and increased consumption (Edwards and Mercer 2007; Rush 2006).

The focus of this paper is on the Serbian institution of gleaning (pabirčenje), which is analysed through diachronic change of institutions and empirical insights. ${ }^{1}$ Taking the village of Gaj in the south-eastern part of Vojvodina province in Serbia as an example, I discuss in detail how such an 
ancient customary practice converted into its antipode. In other words, gleaning, as a relapse of customary welfare, instead of evoking associations related to charity, today rather represents a euphemism for field theft. Many factors have contributed to such understanding. However, two factors seem to be crucial and I will argue that the growing importance of the welfare state and the strengthening of private property have provoked such an outcome.

The converted practice of gleaning acknowledges the opinions of many legal anthropologists who hold that different legal forms are not static but rather are actor-oriented and sensitive to dynamics and change (Turner 2015, 382). ${ }^{2}$ Therefore, the aim of this paper is twofold. As it analyses modifications of the practice of gleaning, which belongs to the sphere of customary law, the first aim of the paper is to contribute to the scholarship on legal pluralism, which understands the law as an analytical conception and a comparable category in cross-cultural and historical analyses, taking into consideration not only variations within state or transnational law, but also various forms of normative orders and unofficial law (F. Benda-Beckmann 2002; BendaBeckmann and Benda-Beckmann 2006; Benda-Beckmann, Benda-Beckmann and Griffiths 2009). More concretely, this paper, with its attention to local ways of negotiating and questioning customary law, may provide a more nuanced approach to cross-cultural research and analyses of legal pluralism. On the other hand, the paper analyses in detail why actors have particular understandings of gleaning, and how they accommodate this practice to their personal needs. Sometimes their actions run counter to the normative and traditional understanding of gleaning, which creates completely new space for manoeuvring traditional norms, and for metamorphosing the institute of gleaning. In that regard, the second aim of the paper is to contribute to the scholarship on informal and informal practices in Eastern Europe, where, according to many authors, various informal practices have become routinised and normalised, particularly since the collapse of socialism as a consequence of failed economic and political reforms (Dunn 2004; Ledeneva 2006; Morris and Polese 2013; Harboe-Knudsen and Frederiksen 2015).

The paper is roughly divided into two parts: theoretical and analytical. My theoretical approach, presented in the first section of the paper, starts from theoretical insights from debate about the impact of the welfare state in the process of crowding out informal welfare. In parallel with this, I observe diachronic developments of institutions of private property and the welfare state in Serbia. This is followed by the second analytical section, in which I present and discuss, apart from the local setting, actors' understanding of gleaning and local strategies related to it.

\section{Debate on Crowding out Informal Welfare}

There is a great body of literature that analyses whether the modern state, known as the welfare state, has contributed to the dismantling of old traditional safety nets and customs. For the sake of simplicity, I shall refer to the latter as informal welfare, although not all such traditional customs, norms and practices have been exclusively dedicated to the support of the welfare of the community or the individual in harsh times. Some of them do not have an altruistic component at all, and their purposes might be quite diverse or purely symbolic. ${ }^{3}$ 
Informal welfare is to be understood as a spontaneously evolved and organized network of institutions (norms and customs) and practices whose aims are to share and mitigate risks (unemployment, natural catastrophes, drought etc.) and reduce the exposure to risk and existential vulnerability (such as poverty, famine, illnesses, growing old) between members of the community or family. From the earliest times, people have been developing different mechanisms for coping with and mitigating risks and hardship. Many of these mechanisms imply the sale of assets, saving, reducing consumption, migration, making alliances through marriage, sharing food, lending and borrowing in reciprocal relationships, diversification of crops and production, income diversification, volunteering, withdrawal of children from school and so on. The nature of risks is various and is caused by different factors. Existing literature distinguishes between idiosyncratic and common risks. Idiosyncratic or individual risks affect only a particular household or individual, while common risks are aggregate, economy-wide, covariate risks that affect all members of a community or region (Dercon 2002, 142). Due to the different effects of risks, idiosyncratic risks can be insured within a community, unlike common risks. In the latter case, everyone within a community is affected, and the consequences usually cannot be shared or insured among members.

Alderman and Paxson (1992) offer two broad classifications of possible strategies to mitigate risk. The first is risk management that is based on anticipation of possible risk, and in accordance with that, activities are oriented towards prevention. In rural areas, this may include crop diversification, income diversification or possibly migration. The second is risk coping strategies, within which individuals and households develop different self-insurance strategies such as saving, accumulating assets or money, or storing goods and food, which enable a household or individual to spread the effects of risk over longer time periods. Risk-sharing is also considered to be a part of risk coping strategies. Risk-sharing rests on different group-based mechanisms that spread the effect of risk at any point in time. People apply various risk-sharing mechanisms in order to reduce the negative effects of risk, such as access to formal insurance schemes, or access to informal insurance arrangements like transfers, remittances, and different labour or land contracts between family and community members. It would be misleading to think, however, that people usually apply one of these two strategies: either risk management or coping strategies. They are often combined and used simultaneously depending on the amount of risk involved.

All these varieties of coping and mitigating risks emerged and developed long before the modern state, and one topical theoretical debate considers whether the modern welfare state endangers informal ways of coping and mitigating crises. Two main approaches have been crystallized so far. The first approach advocates the 'crowding-out' hypothesis. Scholars in support of this stance argue that crowding out of informal welfare appears as an inevitable consequence of the encompassing influences of the state, particularly those in the spheres of social security. 'Rather than relying on private social networks, the welfare state's citizens rely on the state's responsibility to guarantee social benefits in times of need' (Gundelachet et al. 2010, 631). Such situation contributes to social decline because people over time lose the initiative to get involved in social interaction on a daily basis, which induces a passive civil society (see Di Tella and MacCulloch 2002; Gundelach et al. 2010; Cox and Jimenez 1992).

Contrary to this, scholars who support the 'crowding in' hypothesis argue that the state and informal safety nets complement each other, stressing that a more generous welfare state can 
contribute to better informal distribution of help to those in need (Morduch 1999). The cohesive principle that intertwines the state and informal safety nets facilitates the production of social capital and improves the infrastructure of civil society and the very institutions (Rothstein 2001; Torpe 2003).

There are many interesting pieces of evidence to support both approaches. ${ }^{4}$ However, Lucas and Stark (1985) were among the scholars who paved the way for an alternative approach, which offers a more balanced perception of the relation between state and informal welfare systems. Their argument rests on a belief that a combination of self-interest and altruism is crucial for the functioning of informal safety nets. On the one hand, self-interest is a necessary precondition for individuals to enter into different family or community risk-sharing arrangements (such as lending and borrowing, remittances or other private transfers), while on the other hand, altruism creates an ambience of mutual trust that is necessary for maintaining these arrangements. In addition to this, Becker (1974) underlines the importance of social norms and pressures when it comes to good reputation, distinctiveness, being on good terms with neighbours or cousins, benevolence and so on. These factors significantly influence informal welfare and should not be overlooked in theoretical analyses.

Based on this eclectic collection of motives for informal social support, an alternative approach suggests that complete crowding out of informal welfare is unlikely, because social pressures, norms, self-interest and altruism participate in its maintenance, regardless of the size of the welfare state. One of the implications of this approach is that altruism alone is not sufficient, and if private transfers (and informal welfare in general) are based only on altruism and not on self-interest or social norms and pressures, then the complete crowding out of private transfers by public ones is likely to occur (Cox and Jimenez 1992, 158).

Yet, many scholars point to imperfections of informal welfare due to which it declines in front of the state social assistance programs. Informal welfare is particularly fragile when:

- a series of misfortunes accumulate;

- catastrophe affects a broader region and more communities;

- the consequences of an event are irreversible or lasting;

- individuals or families lack human and social capital;

- the costs of risks are very high and unpredictable (Heemskerk et al. 2004, 947).

There are numerous other reasons, such as human factors, which may break down or devitalize different informal welfare mechanisms, particularly risk-sharing. Problems of moral hazard, asymmetric information, and enforcement of mutual reciprocal agreements seem to be prevailing factors that hinder the effective functioning of informal safety nets. Likewise, reciprocal relations very often may convert into patron-client relations, and "the terms of reciprocal exchange may greatly favor the rich, although the terms are to everyone`s absolute advantage" (Morduch 1999, 195). In other words, as social ties are weaker, informal welfare is more subjected to decline or to its replacement by the welfare state, and vice versa.

Lastly, we should also acknowledge here that the revitalization, maintenance or emergence of new informal welfare and supportive networks may appear as a result of a weak and dysfunctional state. For instance, a great body of literature on post-socialism points exactly to the proliferation 
of informal safety nets due to ideological and institutional reorganizations in transitional societies where people become increasingly exposed to uncertainties and risks. In cases when "the state withdraws from the provision of protection from social risks that citizens expect or need, a bottomup process of welfare provision and financing replaces formal welfare provision, citizens 'creating' an informal system of welfare that is independent from the state, but which fulfils the functions that the state should perform" (Polese et al. 2014, 186). Such informal welfare and safety mechanisms do not necessarily follow traditional forms but rather emerge as a transitional, sui generis phenomenon (Polese et al. 2014).

Considering the complexity of each presented approach, the evidence from my fieldwork rather suggests that the first approach, i.e. the 'crowding out' hypothesis, offers the greatest explanatory potential, given that radical transformation of the understanding of practice of gleaning has occurred exactly due to the growing welfare state. Therefore, in the last section of the paper my argumentation will follow the line of this hypothesis. But prior to this, I will analyze institutions of private property and the welfare state diachronically, in order to explain and demonstrate how their change influenced the practice of gleaning.

\section{Diachronic Perspectives of Institutional Change: Private Property and the Welfare State}

\section{Private Property}

When the Kingdom of Serbs, Croats and Slovenians (the KSCS) was established in 1918, Vojvodina province, which became part of the Kingdom in 1918, faced significant discrepancies in terms of property. While private property up to 10 ha $(82.2 \%)$ dominated in Serbia in 1918 , at about the same time big estates over 100 ha dominated over $50 \%$ of the total territory in Vojvodina province (Šećerov 1929). Likewise, while only 11\% of people were landless in Serbia, this number in Vojvodina province was significantly higher and represented $38.8 \%$ of the overall population. Such circumstances created the rationale for the first agrarian reform (1919-1941). One of the crucial aims of the reform was more equal distribution of land to those persons and families who did not have enough land or did not have it at all, in order to avoid structural discrepancies in agricultural development and the ownership structure between Serbia and new member states of the Kingdom. Agrarian beneficiaries in Vojvodina province, for instance, were given ca. 5.8 ha of land, and the planners of the reform foresaw that agrarian beneficiaries should redeem the received land and become its official owners upon completion of the reform. Due to successive financial crises in the KSCS, the world economic crisis in 1925, which had a massive impact on agriculture, and the threat of the Second World War, many agricultural beneficiaries could not redeem their land and hence become its official owners. $\frac{5}{}$

Within the newly formed Socialist Federal Republic of Yugoslavia (1946-1992), the second agrarian reform, conducted immediately after the Second World War, was resting on the principles which saw in private property the biggest threat to socialist society. The Communist party perceived the sole institution of private property as the main "preserver of the bourgeois system and capitalistic class relations" that the new revolutionary system should abolish. Henceforth, the targets of the new reform were all big estates, as well as private property above 10 ha, that had 
been expropriated from the owners without any compensation whatsoever. The reform was aimed at the etatization of all resources and control over means of production. The new politics encouraged indirect subsidies to state farms, the limitation of peasant holdings and the imposition of high taxes on private farming (Halpern 1963). Since the existing agrarian maximum of 10 ha applied both to families and individuals, this encouraged massive property divisions among families or within extended households (zadruga) which survived in some parts of Serbia even after the Second World War (Kaser 2002). While the socialist agrarian reform furthered the vanishing of traditional forms of private property that were kept in zadruga and other similar types of extended families on the one hand, the reform did not reach its planned goal, i.e. the formation of an industrial instead of agrarian society and state agriculture, on the other hand. On the contrary, there were numerous examples of how people managed to preserve and save their landed property by reaching for diverse and creative informal strategies.

The adoption of the 1991 Republic Law marked the end of the existing socialist regulation in agriculture, and enforced restitution of agricultural land, taken from previous owners successively in 1946 and in 1953. More importantly, from 1991 onwards, private property has regained its symbolic (modern) meaning as a free possession, with the free will of the owner to manage his estate in accordance to his preferences. According to the 2012 census, $78.4 \%$ of land in Vojvodina province is in private ownership, whereas in different parts of Serbia, depending on local conditions, the land ownership structure ranges from $41.3 \%$ to $73.8 \%$. Landless people make up $0.13 \%$, while the rest is in state or other types of ownership (Popis poljoprivrede 2012).

It can be said that two social-economic processes crystallized and went along with different ideological and institutional reconfigurations in twentieth-century Serbia. The first was the continuous growth and development of agriculture at the expense of traditional modes of production. The second was sometimes weaker and sometimes stronger fortification of private property at the expense of traditional and collective property relations (Pavković 2014, 284-296).

\section{The Welfare State}

The preconditions for state welfare politics emerged in Serbia during the 1920s. Before this period, social politics was mostly based on voluntary and spontaneous organization of interested parties such as 'Cash of mutual assistance', agricultural credit cooperatives, agricultural supply cooperatives, health cooperatives etc, which should be seen as the pioneers of modern workers and agricultural social politics (Kostić 1929; Isić 1995). The KSCS gained the first common law on social politics in 1922. The law was based on principles of general obligation, universality and mutuality (Čalić 2004, 217). This law had many weakness, but the most notorious ones were the exemption of some professional groups from the law (craftsmen, agricultural producers and attendants), and the temporary suspension of unemployment insurance. In 1938, the law was revised and new categories such as entrepreneurs and craftsmen were included in the system of social insurance. This also referred to disabled and mentally disordered persons and the elderly. Although the revised law encompassed broader categories of people, the KSCS in the late 1930s was at the very bottom of the European average, with only $20 \%$ of the overall population being insured, while the Czech Republic at that time, for instance, had around 50\% insurees. The KSCS 
was also among the European countries with the lowest expenditures for social security, with only $0.6 \%$ of GDP (Čalić 2004, 403-408).

There are many different explanations for why social politics in Serbia and the KSCS in general started to develop relatively late and impartially. Although problems of lack of social insurance existed in South European countries as well, Calić (2004) argues that they were not as severe and obvious as in other Western European societies. She suggests that we might find the reasons for this in the structure of the family and in marriage customs that implied living in an extended family or household (zadruge), and also taking care of old and ill members of the family. Besides, in Serbian tradition, the church and the community played an important role in providing social care, while the state was not seen as a primary social protector. But maybe the predominant reason is to be found in the economy of the KSCS, which was based mostly on small and medium enterprises, where concentration of industrial workforce could not occur. The majority of workers had worked only periodically in factories, while maintaining their main occupation, which was agriculture (220). In the late 1930s the worker structures started to grow, change and professionalize, as did their understanding of social politics.

Building the welfare state was one of the goals of the newly established Socialist Federal Republic of Yugoslavia. The state took over the majority of activities related to social services, increasing social care and provisions. As the socialist state saw in patriarchal culture the main enemy of modernization, the dismantling of old patriarchal and traditional ties was strongly encouraged through a range of processes, such as increasing employment of women, establishing day-care for children, providing maternity leave and benefits, urban migration etc. The appearance of new social risks, marginalized groups and social exclusion were, apart from other factors, consequences of dismantled traditional family relations and informal safety nets. Among new vulnerable groups appeared old people, the handicapped, mentally disordered persons, children and juvenile delinquents, so the state had to develop a whole network of different services that would meet their needs, such as day care, health, educational and therapeutic centres and so on.

Until the collapse of Yugoslav socialism in 1991 the state undertook the role of main welfare provider by developing its channels through which national resources were further distributed. State branches and centres for social work were organized in the 1960s in order to recognize, analyze and better treat local problems and needs. Around the same time period, centres for social work started to be financed by local municipalities, and state enterprises took over some segments of social policies in the late 1970s, fostered by the ideology of Yugoslav self-management socialism (Šućur 2003). In this way, domains of work and production took over social function, which should be the responsibility of the state in all democratic countries (9). The growing and overprotecting Yugoslav social politics, however, could not meet the set goals and needs of insurees due to the frequent financial crises. To name a few, the state was faced with a massive increase in the number of pensioners, due to which agricultural producers were included in the compulsory pension insurance scheme only in the mid-1980s. The socialist economy was under pressure from the growing workforce as a result of rural-to-urban migration. Instead of caring for employees in socialist companies and the public sector, the social policy was directed towards unemployment, which became the burning issue (Grandits 2012).

The collapse of socialism on former Yugoslavian territory did not bring about significantly new developments in terms of the welfare state, as many theoreticians of post-socialism had 
predicted. The great body of post-socialist literature, apart from emphasizing that countries of Eastern and Central Europe cannot be perceived as a homogeneous region with regard to the welfare state, points to the fact that they share certain commonalities either in withdrawal of the state, structural mutations or in the lack of a social state due to embracing the neoliberal paradigm (Szikra and Tomka 2009; Cook 2007; Polese et al. 2014; Deacon 2000). My evidence, however, runs counter to this dominant argumentation. When Yugoslavia broke apart, all former member states preserved the existing concept of the welfare state. The main differences, though, concern institutional decentralization, professionalization and diversification, along with higher presence of the NGO sector, foreign and domestic donors, and community-based services. In Serbia, for instance, the main financier of social services remains the state or the local government, with over $55 \%$, while NGOs make up $23 \%$ of the overall share in the provision of social services. Since 2008 , the total number of social services financed by the local government has increased as well. The same is true for social beneficiaries. "Since 2000, the number of recipients of insurance based benefits has almost doubled, regardless of the legal changes making effectuation of the rights stricter" (Vuković and Perišić 2011, 241). Likewise, the last few years register a positive trend of NGOs that are financed by the state, particularly in domains of social protection of youth, Roma, gender equality, and similar issues in the field of social exclusion (Vuković 2013, 67-72).

I would like briefly to demonstrate the impact of the growth of the welfare state in Serbia. Expenditures for social security were $24.6 \%$ of GDP in 2010, which is an impressive increase if we take into consideration that they were only $0.6 \%$ of GDP in the $1930 \mathrm{~s} . \underline{6}$ Expansion of the welfare state certainly left some consequences, which are visible in the very low participation of citizens in humanitarian $(1.2 \%$, , religious $(3.9 \%)$ or environmental $(1.1 \%)$ initiatives. This may be an indicator of the underdeveloped civil sector in Serbia (Vuković 2013, 68). Moreover, this evidence strongly contributes to the hypothesis of crowding out of civic interests and the informal organizing of people by the welfare state. In what follows, I will try to demonstrate and analyze how the expansion of the welfare state, but also the strengthening of private property, affected social actors and their understanding of the practice of gleaning.

\section{Blurred Lines of Gleaning - the Case of Gaj}

The village of Gaj is located in the South Banat District in Kovin municipality, within the Vojvodina province. Gaj lies on a flat and fertile terrain with the Danube River flowing along the southern edge of the village over a length of $7 \mathrm{~km}$. With a population of almost 3000, this village is among the most populated ones in the area. The village community is highly multicultural and relatively harmonious, with Serbs as the majority and Czechs, Romanians, Hungarians and Roma as minorities.

During the socialist period, a part of the village population was employed in state companies, industries or in the public sector in nearby cities. A large number of these companies are now closed or are becoming insolvent, leading to many people losing their jobs. There are two relatively successful companies in the village. One is a coal mining company and the other is a privatised agricultural enterprise. 
The local population, both unemployed and employed in state or private companies, cultivate land, while livestock breeding is in constant decline. The average area of cultivated land per household ranges between 5 ha and 20 ha. This usually depends on several factors, such as the number of people living in a household, age structure, or additional professional occupations of the family members. According to many informants, at present some twenty people from the village stand out from the others in that they cultivate more than 100 ha. On the other hand, mainly professionals such as doctors, veterinarians, lawyers, professors, teachers, and a large percentage of Roma belong to a tiny group of people without any land (or possessing only small amounts). From the perspective of state social politics, the most vulnerable categories in Serbian villages, including Gaj, are old people and Roma: the former due to very low pensions (if they are pension beneficiaries) and frequent neglect by family, health and social institutions, and the latter because they are mostly unemployed, uneducated and landless.

Apart from being relatively prosperous, the village of Gaj faces the typical problems of rural Serbia, such as a high mortality rate, unemployment, aging and outflow of youth, negative population growth and an increasing number of single persons. However, the majority of informants stress one problem in particular. That is the increased number of field thefts since 2000 . Investigation of the reasons behind field thefts initially has led me to unexpected and uncommon local understandings of the practice of gleaning from both agricultural producers on one side, and Roma, who are signified as the main field trespassers in the village, on the other side.

\section{The Practice of Gleaning}

There is a universal logic adapted to the physical fact that we are surrounded by limited space. Such logic developed various patterns of entitlements to use land that became intrinsic to every social organization (Ellickson 1993). Every region, be it agricultural or mountainous, has developed its customary rules related to use and access to agricultural fields and other natural resources, collective property rights and reciprocal relationships. Property, as a concept and an analytical tool, is one of the most important concerns of legal anthropology (F. Benda-Beckmann, K. Benda-Beckmann, and Wiber 2006). The pioneers of legal pluralism, Franz and Keebet von Benda-Beckmann, defined property as "a bundle of rights and relationship between persons forged around valuable goods material and immaterial" (F. and K. Benda-Beckmann 2014, 20).

'Such bundles comprise four major elements: (1) construction of property objects from material and immaterial parts of the social and physical environment; (2) definition of social units that can be the bearers of property rights and obligations; (3) relationships bound in the framework of rights and obligations; and (4) spatio-temporal dimension' (F. and K. Benda-Beckmann 2014, 21).

The second and third elements of this definition will be of special concern for this section: that is, social units that can be the bearers of property rights and obligations; and relationships that emerged within the framework of rights and obligations.

Diachronic analyses of developments of customary law, which concern the domain of land rights in particular, are important for understanding today's practices, which rely on custom and its acknowledgement by official, state, law and vice versa, but also for understanding the complexity of legal plurality in certain settings (F. Benda-Beckmann and K. Benda-Beckmann 
2006). The institute of gleaning most likely emerged as an obligation that landowners held towards their social environment. The right to glean was thus regulated by customary law that served as a mechanism for acquiring social equilibrium when dearth, poverty and landlessness were socially widespread. Probably for the same reason, almost every agricultural society had known practices that were based on the same or similar patterns. The institution of gleaning should be understood as one of many existing facets of collective property. Pavković (2014) also argues that collective rights over private property exist almost everywhere.

\begin{abstract}
'When the harvest is reaped on an arable land, it temporally becomes common. Everyone has the right to bring cattle to graze on it, or to glean it, i.e. to collect grains of wheat, clips of corn, or grapes in a harvested vineyard. From this originated the old proverb: To find oneself in a non-harvested vineyard ("Naći se u neobranom grožđu" J. D.), i.e. in legally or morally impermissible act or situation. The message is clear: you can glean in a harvested vineyard, but should not find yourself in a non-harvested one!' (Pavković 2014, 287).
\end{abstract}

One important remark should be made here, though. Collective property, generally common in many parts of the world, was primarily related to pasture breeding in south-Slavic countries and south-eastern Europe, while on the other side, arable lands were exclusively in private or family ownership (Pavković 2014, 284-296). While in the first case collective property entitlements automatically evolve from common territorial, kinship or tribal belonging, in the latter case the notion of consent is necessary in order to authorise gleaner's rights. The consent may be explicitly gained from the landowner, or it can be implicitly, culturally and customarily, communicated and accepted. The temporary right to glean on private land therefore classifies this right in the sphere of collective property rights. This in-betweenness of the practice of gleaning, as will be shown later, makes the very right suitable for different interpretations.

The next aspect is also very important for the practice of gleaning. Although on the surface it may seem that the practice of gleaning was pure charity, in the sense that an altruistic landowner does not expect anything in return from gleaners, I rather maintain that the practice itself has always been based on reciprocal relationships and utility. We have to consider social variables such as distinction, a good name or benevolence as important components of reciprocity, and as integral elements of any given social interaction. The famous utilitarian philosopher Jeremy Bentham ([1781] 2000) calls these social variables pleasures.

'The pleasures of benevolence are the pleasures resulting from the view of any pleasures supposed to be possessed by the beings who may be the object of benevolence' (X, 37).

'The pleasures of a good name are the pleasures that accompany the persuasion of a man`s being in the acquisition or the possession of the good-will of the world about him; that is, of such members of society as he is likely to have concerns with; and as a means of it, either their love or their esteem, or both: and as a fruit of it, of his being in the way to have the benefit of their spontaneous and gratuitous services. These may likewise be called the pleasure of good repute, the pleasure of honour, or the pleasures of the moral sanction' (VII, 36).

Benevolent and charitable actions are not therefore motivated merely by material but also by symbolic drivers, particularly in traditional communities. Benevolence and charity at least may be extorted. Even if they are seemingly voluntary, they may be often necessary and sometimes forced (Pavković 2014, 334-340). In the everyday life of the community, all social interaction is based 
on well-recognized norms of exchange and reciprocity (Foster 1973, 105). The landowner's generosity towards many landless people for whom gleaning was sometimes the only way to survive had at least three facets. The first was social-symbolical, the second was politicalinstrumental, and the third was economic. The first was aimed at building the landowner's reputation in the community (his good name, in Bentham's understanding), extending and strengthening his social network, which evolved by doing favours for his subordinates or taking them into his protection. In this way, the landowner engaged in establishing his clientalistic network among his subordinates, who would repay him later for his generosity by supporting him in his political ambitions. The second facet of the landowner's generosity was consequently political-instrumental. By allowing the poor to glean his field, the landowner met their existential needs in the short run, but in the long run he prevented prospective social unrest on his own property, and acquired for himself stable political support among local population. Finally, it should not be forgotten that landowners' generosity probably also had a purely economic aspect. Landowners' opportunity costs were minimal or negligible. The immediate cost of an alternative, such as not letting gleaners into his field, would have caused more troubles and unrest. In other words, after the field has been harvested, the landowner would not suffer any economic losses by letting gleaners into his field, while his social and political gain would be much higher in the long run. ${ }^{7}$

\section{The New Understanding of the Practice of Gleaning}

Subsequent developments in agriculture and in the welfare state have had a decisive impact on the changed perception of gleaning. In socialist Yugoslavia, the category of landless people officially disappeared, due to the inauguration of three different types of ownership: collective, state and private. Besides, the state took over the role of the welfare patron. After the collapse of socialism, the liberal-democratic transition gave private owners the right to enlarge their property without any restrictions whatsoever, while the state has remained the main provider of welfare. Private property and the welfare state have evidently been developed over the years at the expense of the practice of gleaning. In previous times, gleaning evoked connotations of social, economic and political reciprocity. Today, in the context of rural Serbia, it often represents a euphemism for field

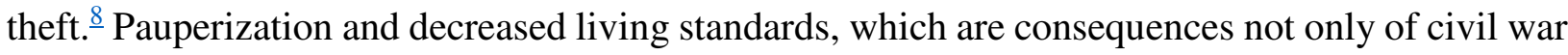
in former Yugoslavia (1991-1995) but also of failed transitional economic and political reforms in Serbia after 2000, have amplified the rate of criminality in the cities and in villages respectively.

The majority of people in the village of Gaj relate the rise of criminality to Roma. Recent population surveys and research show that Roma are among the most vulnerable and marginalized population in Serbia. Their deprivation is intergenerational and creates a continuous poverty trap (Bodewig and Sethi 2005). For this and similar reasons, such as massive unemployment, high poverty and low hygiene standards, as well as the traditional stigma of being 'thieves' and unreliable persons, Roma represent a socially marginalized group in the village of Gaj.

People often suggestively commented in my presence on how is it possible that they have 'full barns of corn, when they have neither land nor machines', or ironically asked themselves, 'Where were Roma working late hours when their horse carriages are full of corn?' Sometimes, when they 
spotted Roma cruising on their carriages toward fields in the late afternoons, they would tease each other about whose plot would be 'gleaned' next. In the long summer nights while my neighbours and I were having sabor, ${ }^{9}$ I heard many stories how some nearby villages had resolved the problem of field thefts. Villagers would join and share costs of hiring private security company with rangers who were surveilling their fields, and were equipped with fast terrain jeeps and cameras. This allegedly gave positive results because many Roma from these villages sold their horses and carriages.

Obviously this was not the case in Gaj village, and many people expressed their bitterness towards authorities in Kovin municipality because of their incapability to protect peasants' property.

'People are revolted because of the field thefts. Roma steal. I was robbed of 1 ha of corn. They have now started to steal sunflowers, which was not the case before. They even steal clover. Everyone knows who steals but peasants cannot do anything. For this reason they themselves protect their own fields. They wake up at 2-3 am, take their guns and surveil their fields' (P. K. 20. 06. 2013.).

Even though Kovin municipality has recently hired two field watchers, who initially patrolled on bicycles and subsequently on motorbikes, this was not enough to watch over and protect the whole village territory, which spreads over a dozen kilometres.

'Field watchers don't have great authority: that's an issue. They must not use force. They have rather the function of tallyman. If field theft or damage occurs, they take a picture, ascertain the theft, and forward the report to the authorities that are supposed to initiate investigation. (...) Despite the field watchers, I was robbed of half a chain of corn. $\frac{10}{}$ Now I should take the report and sue the municipality because I was robbed. The municipality bears the costs of field watchers, not the village' (S. S. 08. 04. 2013.).

On the other hand, a field watcher emphasized the structural problem of the field thefts in the village:

'The fear protects the field, not the field watcher. We have a contract from the first of April till November. We do nothing during winter, because we are not authorized. The problem is that our authority that we built during summer declines over winter' (M. P. 19.07.2013).

Thieves are, according to the field watcher, rarely brought to justice or made to take responsibility for their acts, whether due to political tolerance on the local and republic level or their financial insolvency. The local policeman greatly supports the field watcher's opinion and adds that this may be due to the fact that field thefts are hardly provable and are generally considered to be of low value. One of the main problems, according to him, is that the police can only initiate an investigation: once the prosecutor takes over the case, the damaged party has to sue the thief on the basis of a private lawsuit. 'This almost never happens because the game is not worth the candle (Skuplja dara nego mera). So, the damaged person is never reimbursed, while on the other hand the prisons are full and field thieves never end up in prison' (D. S. 18. 07. 2015.).

State social politics are partially to blame for increased field thefts. In the interview with the social worker form Kovin municipality I learned that state social politics over the years have moved towards insuring unemployed people who are capable of working, which was not the case only ten to fifteen years ago. Roma capable of working almost automatically become social beneficiaries on different bases (being unemployed, single mother or father, illness, child benefits 
etc.), but those who have no children or have only one child do not receive unemployment benefits over the whole year. They are entitled to unemployment benefits for the first six winter months, after which these benefits are temporarily suspended during the three summer months because it is believed that beneficiaries can find seasonal work, or can be hired as wage labourers during the harvest. After the summer they re-enter the social protection system for the rest of the year. There are also certain limitations regarding child benefits. Roma and other social beneficiaries are entitled to receive child benefit allowance for up to four children until they reach the age of 18 (for the first four children born), despite the actual number of children. In reality Roma usually have more than four children. Probably due to these restrictions, Roma try to overcome their financial difficulties by applying different strategies.

From the perspective of a social worker from Kovin municipality, in spite of these existing limitations of social provisions, new social politics towards Roma do not encourage them to work; nor do they create a supportive work environment.

'Together with unemployment benefits and subsided prices for communal services and electricity, plus child benefit, maternity benefit, parental benefit etc., they have enough regular income for living. If they need something in addition to this, then they find a way, they will work for a while. Some do not even need to work. They are absolutely demotivated to work' (Social worker, 1. 08. 2014).

The perspective of a local shopkeeper from the Roma quarter in Gaj village is unsurprisingly different. The shopkeeper's assessment of the real standard of living of the Roma on the basis of their daily consumption and regular encounters with them suggests that they live the worst during winter because they do not have many opportunities to diversify their income and hence rely only on social benefits, while during the summer months the situation is somewhat different.

'Roma make up approximately 15 per cent of Gaj's population. They cope somehow. They collect steel, iron, aluminium, receive social benefits. I see that according to their daily incomes. But during winter it is harder: they cannot work and there is no job on the horizon' (T. M. 12. 07. 2013.).

The shopkeeper's opinion supports the personal testimony of one of my Roma informants who applies gleaning as a strategy for diversifying income and overcoming shortcomings in the family budget: 'We receive only two child benefits. We hardly cope. We do not eat three times a day... but then, well, then with the summer comes corn ...' (I. Ž. 18. 07. 2013.). The fact that gleaning is broadly practised among the Roma as a summer strategy to overcome financial difficulties is confirmed by a school teacher, who expressed very emotionally in an interview how Roma parents come to ask his permission to let their children off school for a couple of days in order to help them in gleaning. Another Roma informant admitted that in previous years his family would glean from four to five tons of corn and would sell it for 'nice money'. This money served them as a saving for the winter, or for firewood.

However, there is considerable common understanding among the people of Gaj village that the deep poverty and existential needs of the Roma are to be the responsibility of the centre for social work, which takes care of vulnerable groups at the local level. Such understanding was best summarized in the interview with the president of the association of pensioners from Gaj village. Referring to the functioning of the association's safety network, the president said: 'We do not help Roma, although we have Roma members whom we treat equally. Other Roma (non-members - J. D.) who ask for money or food from us, we direct to the Red Cross or to the Centre for Social 
Work' (N. I. 03. 07. 2013.). As described in the previous pages, due to the growing welfare state over the years, Roma were crowded out from local and informal welfare networks and became an official social category subjected to different state social programs and provisions. But interestingly, existing restrictions in unemployment and child benefits unexpectedly bring to the fore the importance of local informal welfare, i.e. gleaning. Roma realize that this gap as well as shortcomings in formal care give them a rationale for activating old customary patterns in order to overcome their financial difficulties.

The practice of gleaning, as indicated above, nowadays rarely invokes sympathy among villagers because, apart from being identified with theft, it is also related to serious violence and improper conducting of justice by authorities, which provokes anger.

'Thefts are everywhere. We cannot stop the thieves. They enter into fields freely, and even if someone sees them they don't pay attention to it at all. Although we have field watchers there is no difference. Five or six years ago one field watcher almost got into serious trouble for shooting the thief. The whole village signed the petition to save him, while thief passed without any consequences' (Lj. R. 11. 07. 2013.).

Besides, field thieves sometimes cause serious field damage. There have been a few cases when field thieves burned corn stubble in order to bring them to the ground and then simply picked clips of corn. This gleaning technique has caused several fires, but since the culprits were not prosecuted, the landowner himself had to pay for the damage. One of my informants reckons that Roma usually glean in a safer way, due to which evidence of field theft is not immediately visible. Two or three men glean a harvested field, while another group steals corn in the middle of a neighbouring non-harvested field. The visible group acts as cover for those who are invisible in the neighbouring field either to random passers-by or to field watchers. Gleaning as a practise certainly cannot be constrained only to theft, but thieves have contributed a lot to the changed perception of the practice among villagers and landowners.

'Those who have stolen have made us a problem. Because of them we are forbidden now to glean. Many didn't want to work hard and to collect corn from the ground, because it was easier for them to pick corn from stubble. I understand landowners: they have invested a lot in land and maybe have had either drought or flooding, and as a culmination someone has stolen their corn. They've had enough' (S. R. 17. 07. 2015.). $\frac{11}{}$

Large numbers of people consider gleaning nowadays as a subversive practice, which partly explains why it is believed that little remains of the old practice of gleaning. Likewise, the term 'gleaning' is used by some Roma as a euphemism for theft. The new understanding of the practice of gleaning is devoid of its main impulse - reciprocity. In a strict sense, the name of the practice is kept, but the nature of the practice itself and its symbolism have changed radically. It has converted into a one-sided practice that no longer has any social purpose apart from satisfying the short-term existential needs of the gleaners.

One crucial aspect of the practice of gleaning in the past was explicit or implicit consent. According to one of my Roma informants, gleaners in Gaj village usually did not ask for explicit consent from the landowner, relying instead on implicit, customary and socially acceptable norms of old practice. Likewise, the customary in-betweenness of the right to glean - that is, the temporary collective right over private property - gives gleaners a certain legitimacy to claim their rights today. They apply a traditional understanding of gleaning and the rights associated with it 
in order to restore the status quo ante (see Scott 1976, 157-192). On the other hand, those who steal use a traditional understanding of the practice, thus evading social criticism, potential sanctions, and involvement in the theft. Such strategy minimizes the social burden of theft. One of my Roma informants rationalizes field thefts in the following way:

'There are many Roma who steal, but there are also those who don't. We are among the latter. Many hardly live and they do not have other options but to steal. One cannot live from social benefits, particularly not during winter when we have to pay for electricity and firewood. With 13000 RSD (approximately 107 EUR - J.D.) that we get in the name of social benefits we have to pay either for the firewood or for the pig for the winter. We have to find 20000 RSD (approximately 165 EUR - J.D.) for this. We don`t have that money. The situation is somewhat better in the summer months (S. R. 17. 07. 2015.).

This brings us to consideration of an important aspect that lies beneath the practice of gleaning which is usually forgotten in daily life, but gives strong credo to today's gleaners. Invoking the old practice of gleaning has to do with a subsistence ethic that was present particularly in traditional communities. As Scott argues, 'the fear of food shortages has, in most pre-capitalist peasant societies, given rise to what might appropriately be termed a "subsistence ethic" (Scott 1976, 2). The universality of this ethic emerged as a result of the centuries-old experience of living close to the margin, facing threats of famine and diverse natural catastrophes, which consequently have developed a special ethical universe where existing social relations primarily have the purpose of insuring the poor. Many social arrangements, therefore, such as patterns of reciprocity, forced generosity, communal land, and work-sharing, aim to even out existing differences in a family`s resources which might otherwise have thrown them below subsistence (Scott 1976, 3). Economic relations that are based on a special notion of what is just and unjust, as well as of rights that have emerged within a subsistence ethic, are among what scholars have called the moral economy, a term that was firstly inaugurated by E. P. Thompson. According to Scott, the moral economy represented the normative roots of peasant politics and society worldwide. Underneath this normative order is the safety-first principle, which manages crucial economic, social and moral relations in the peasant community (Scott 1976, 1-12). The safety-first principle is based on the idea of redistribution of all available resources within the village or community, whether communal or private, in order to meet the elementary and subsistence needs of members in need.

It seems that embedding the practice of gleaning in an old normative order of peasant society today legitimizes certain expectations among the Roma. As they mostly belong to a group of the poorest in the village, their hopes rely on old sympathies and understanding related to gleaning, i.e. the right to subsistence that this practice used to provide. They try to maintain continuity with the old practice, which represented a legitimate and socially acceptable act in the past, regardless of what kind of actual activity is going on in the name of gleaning. Even though the context has changed - the welfare state and private property have evolved as new bearers of social security Roma, through the survival of the old understanding of gleaning, maintain connections with the informal welfare from which they have been largely crowded out. 


\section{Conclusion}

Within customary law, the institute of gleaning served in the past as a form of informal welfare, based not only on charity but also on mutual supportive mechanisms for both actors involved: landowners and the poor. This paper shows how such an ancient institute of customary law survived the era of socialism and mutated in the transitional, post-socialist setting when people were enabled to freely expand their private property, strengthening their sense of ownership. Due to the growing welfare state, which undermines local ways of informal safety networks and organization and contributes to transferring responsibility for local wellbeing to the upper state level, but also due to the growing number of private property owners, frequent field thefts have brought about a changed perception of gleaning among people in Gaj village. Indeed, on the other side, those who glean are potential culprits under constant suspicion. Conditionally speaking, this custom can be considered as an "empty custom" because its intrinsic components, commonly shared meanings, rules and obligations, are not evenly communicated between actors, which is one of the necessary preconditions for its proper functioning. Finally, the question is, can we still talk about traditional gleaning?

\section{Acknowledgments}

I would like to thank two anonymous reviewers and the editor of this issue for their very constructive and helpful comments and feedback.

\section{Funding}

This work was supported by the Swiss Government Excellence Scholarship for foreign students, which I have been granted for three years' PhD research starting from 2013 as a student at the Department of Social and Cultural Anthropology, University of Zurich. Hereby I would like to express my special gratitude to the Federal Commission.

\section{Disclosure statement}

No potential conflict of interest was reported by the author.

\section{Notes}

1. This paper is a result of broader doctoral work that investigates everyday strategies in rural Serbia in the postsocialist period, with special emphasis on agricultural, economic and institutional changes. The village of Gaj is the epicentre of my observation where I conducted extensive field research in 2013, one month in 2014 and in 2015. The findings presented in this paper are a very partial reflection of overall data that I gathered through participant observation and in-depth semi-structured interviews with over eighty informants.

2. This may also refer to the renewed emphasis on tradition. According to Turner (2015), this is not an indicator of state failure or of reactionary rejection of globalization. Rather, the dynamic capacities of tradition allow different actors, on the global and local scale, to "invoke tradition as a strategic tool in legal repertoires to further their respective interests, ranging from development goals such as sustainability, nature conservation and good governance to absolute hegemony in the religious field" (387). 
3. Many economists rightly point out that it is very hard to estimate and evaluate the real purpose of informal transfers and distributions among community members or family. Some of them need not be the result of risksharing, or are not necessarily aimed at improving a person's or a community's wellbeing. Alderman and Paxson $(1992,71)$ suggest that simply documenting that transfer exists between donor and recipient does not imply risksharing. For instance, migrants may send remittances to increase their chances of inheriting family assets, or to pay families back for the costs of their education (71). On the other hand, some transfers may also be driven by purely altruistic reasons, when donors do not expect anything in return. In such cases they may be treated as gifts by both parties: donor and recipient.

4. Di Tella and MacCulloch (2002) show, for example, how increased generosity of state benefits makes defecting from the informal family risk-sharing contracts more attractive, and likewise affects the increment of the unemployment rate. In a similar fashion, Cox and Jimenez (1992) indicate that the amount of private transfers from young to old would have been almost 20 percent larger in Peruvian families without different social security programs. On the other hand, a very interesting study by Gundelach et al. (2010) on the impact of the size of the welfare state on informal volunteering in Swiss cantons does not find any critical impact of welfare state arrangements on informal volunteering. Instead they argue that socio-cultural conditions are more important determinants of informal volunteering than the welfare state. In their ethnographic study on rural Latin America, based on interviews with welfare recipients, Heemskerk et al. (2004) conclude that access to state transfers does not replace informal insurance systems, particularly in reference to food sharing, reciprocal labor, or religious ceremonies. State social benefits increase the amount of transfers in existing exchange networks, and consequently contribute to better functioning of reciprocity when there is more to share (951).

5. The first agrarian reform, although impartial and inconsistent in some segments (see Lekić 2002, 117-139), should be seen as institutionalization of private property and the beginning of capitalist relationships in agriculture. Nevertheless, tendencies of individualization of private property, as well as gaining its institutional sovereignty in relation to family, social and political organization, were severely disrupted in the era of socialism.

6. http://www.novimagazin.rs/ekonomija/srbija-za-socijalnu-zastitu-izdvaja-manji-deo-bdp-od-eu (Accessed May 24, 2015).

7. I owe this insightful remark to my supervisor, Professor Peter Finke, from the Department of Social and Cultural Anthropology, University of Zurich.

8. Three recent newspaper articles have discussed the problem of the relationship between gleaning and field thefts, showing that field thefts are not only a problem in Vojvodina province but also in other agricultural regions in Serbia. The first two articles reflected on the practice underneath the gleaning, i.e. field theft. The third article offered a more philosophical argument that gleaning negates the sanctity and absoluteness of private property rights. Nevertheless, what all three articles have in common is that they understand gleaning as subversive practice. See: http://www.pressonline.rs/svet/balkan/182860/pabircenje-ili-kradja-kukuruza.html (Accessed October 24, 2011). http://juznobanatskevesti.rs/info-servis/item/365-za-pabircenje-je-potrebna-dozvola-ili-vasceka-kazna\#.VWOEvk-qqkp $\quad$ (Accessed $\quad$ October $\quad 15, \quad$ 2013). http://www.danas.rs/danasrs/dijalog/skvoteri_pabircenje_i_kralj_mida.46.html?news_id=265656 (Accessed August 8, 2013).

9. A very traditional way of spending free time on the benches in front of the house together with neighbors during spring and summer afternoons and nights. In previous times, every small quart or street in the village had its own sabor. Today it is mostly practiced by older people, although there are some younger families and persons who either gladly join or regularly practice sabor.

10. The chain of land (lanac zemlje) is a local unit of measurement for land area. A chain of land equals 57.6 ares.

11. According to my informant, due to increased field thefts and frequent complaints from agricultural producers, the council of Gaj village made the decision that gleaning is forbidden from this year on. Only if a person obtains signed consent from the landowner will the council allow gleaning. Given the fact that I was not in a situation to meet members of the council during my last field visit, I cannot treat this information as fully confirmed. However, if the information is correct, this would be the first time that the ban has been delivered on the upper council level, because previously the hallmark of forbidden gleaning was, and in some places still is, a scarecrow at the very entrance of the certain field which is placed there by the landowner himself. 


\section{References}

Alderman, H., and C. H. Paxson. 1992. Do the Poor Insure? A Synthesis of the Literature on Risk and Consumption in Developing Countries. Policy Research Working Paper Series No. 1008. Agricultural policies. Washington, DC: World Bank.

Becker, G. 1974. "A Theory of Social Interactions" Journal of Political Economy 82 (6): 1063-1093.

Benda-Beckmann, F. von and K. von Benda-Beckmann. 2006. "The Dynamics of Change and Continuity in Plural legal Orders" The Journal of Legal Pluralism and Unofficial Law 53-54: 1- 45.

Benda-Beckmann, F. von, K. von Benda-Beckmann \& A. Griffiths, eds. 2009. The Power of Law in a Transnational World. Anthropological Enquires. New York, Oxford: Berghahn Books.

Benda-Beckmann, F. von, K. von Benda-Beckmann \& M. G. Wiber, eds. 2006. Changing Properties of Property. New York, Oxford: Berghahn Books.

Benda-Beckmann, F. von. 2002. "Who's Afraid of Legal Pluralism?" The Journal of Legal Pluralism and Unofficial Law 34: 37-82.

Bentham, J. (1781) 2000. An Introduction to the Principles of Morals and Legislation. Reprint, Kitchener: Batoche Books.

Bertram T. 2015. "Exploring avenues of research in legal pluralism: forward-looking perspectives in the work of Franz von Benda-Beckmann." The Journal of Legal Pluralism and Unofficial Law 47: 375410.

Bible, King James Version. The Story of Ruth 2: 2-23

Bodewig, C. and A. Sethi. 2005. Poverty, Social Exclusion and Ethnicity in Serbia and Montenegro: The Case of the Roma. http://web.worldbank.org/archive/website01502/WEB/0_CON-9.HTM, (Accessed February 10, 2016)

Čalić, M. Ž. 2004. Socijalna istorija Srbije 1815-1941 [Social History of Serbia 1815 - 1941]. Beograd: Clio.

Cook, L. 2007. Postcommunist Welfare States Reform Politics in Russia and Eastern Europe. Cornell University Press.

Cox, D., and E. Jimenez. 1992. "Social Security and Private Transfers in Developing Countries: The Case of Peru." The World Bank Economic Review 6 (1): 155-169.

Deacon, B. 2000. "Eastern European welfare states: The impact of the politics of globalization." Journal of European Social Policy 10 (2): 146-161.

Dercon, S. 2002. "Income Risk, Coping Strategies, and Safety Nets." The World Bank Research Observer 17 (2): 141-166.

Di Tella, R., and R. MacCulloch. 2002. "Informal Family Insurance and the Design of the Welfare State." The Economic Journal 112 (481): 481-503.

Dunn, E. 2004. Privatizing Poland: Baby Food, Big Business, and the Remaking of Labor. Ithaca: Cornell University Press.

Edwards F. \& D. Mercer. 2007. "Gleaning from Gluttony: an Australian youth subculture confronts the ethics of waste." Australian Geographer 38 (3): 279-296.

Ellickson, R. C., 1993. "Property in Land." The Yale Law Journal 102: 1315-1400.

Foster, G. 1973. Traditional Societies and Technological Change. New York: Harper \& Row Publishers.

Grandits, H. 2012. "Kinship and the Welfare State in Croatia's Twentieth-Century Transitions." In Household and the Family in the Balkans. Two Decades of Historical Family Research at University of Graz, edited by K. Kaser, 453-478.Vienna: Lit.

Gundelach, B., M. Freitag and I. Stadelmann-Steffen. 2010. "Making or Breaking Informal Volunteering: Welfare Statism and Social Capital in a Sub-National Comparative Perspective." European Societies 12 (5): 627-652.

Halpern, J. M. 1963. "Yugoslav Peasant Society in Transition - Stability in Change." Anthropological Quarterly 36 (3): 156-182. 
Harboe-Knudsen, I. and M. D. Frederiksen. 2015. Ethnographies of Grey Zones in Eastern Europe Relations, Borders and Invisibilities. Anthem Press.

Helmke G, S. Levitsky. 2004. "Informal Institutions and Comparative Politics: A Research Agenda." Perspectives on Politics 2 (4): 725-740.

Isić, M. 1995. Seljaštvo u Srbiji 1918-1925 [Peasantry in Serbia 1918-1925]. Beograd: Institut za noviju istoriju Srbije.

Kaser, K. 2002. Porodica i srodstvo na Balkanu: analiza jedne kulture koja nestaje [Family and Kinship in the Balkans: an Analyses of a Culture which Disappears]. Beograd: Udruženje za društvenu istoriju.

Kostić, S. 1929. "Socijalna politika sela." [Social Politics of Village] In Naše selo [Our Village], edited by M. Stojadinović, 534-546. Savremena opština.

Ledeneva, A. 2006. How Russia Really Works: Informal Practices in the 1990s . Cornell University Press.

Lekić, B. 2002. Agrarna reforma i kolonizacija u Jugoslaviji 1918-194 [Agrarian Reform and Colonisation in Yugoslavia 1918-1941]. Beograd.

Lucas, R., and O. Stark. 1985. "Motivations to Remit: Evidence from Botswana." The Journal of Political Economy 93 (5): 901-918.

Morduch, J. 1999. "Between the State and the Market: Can Informal Insurance Patch the Safety Net." The World Bank Research Observer 14 (2): 187-207.

Morris, J. and A. Polese, eds. 2013. The Informal Post-Socialist Economy: Embedded Practices and Livelihoods. Routledge.

Pavković, N. 2009. Banatsko selo: Društvene i kulturne promene: Gaj i Dubovac [Banat Village. Social and Cultural Changes: Gaj and Dubovac]. Novi Sad: Matica srpska, Odeljenje za društvene nauke.

Pavković, N. 2014. Studije i ogledi iz pravne etnologije [Studies and Insights from Legal Ethnology]. Beograd: Etnološka biblioteka.

Polese, A, J. Morris, B. Kovács \& I. Harboe. 2014. "Welfare States' and Social Policies in Eastern Europe and the Former USSR: Where Informality Fits In?" Journal of Contemporary European Studies 22 (2): 184-198.

Popis poljoprivrede 2012. Poljoprivredno zemljište u Republici Srbiji [Agricultural Survey 2012. Agricultural Land in Republic of Serbia]. Republički zavod za statistiku.

Rothstein, B. O. 2001. "Social Capital in the Social Democratic Welfare State." Politics and Society 29: 207-241.

Rush, E. 2006. Skip dipping in Australia, Australia Institute, Canberra.

Scott, J. 1976. The Moral Economy of the Peasant. Rebellion and Subsistence in Southeast Asia. Yale University Press.

Šećerov, S. 1929. "Stanje agrarne reforme i putevi za rešavanje." [The State of Agrarian Reform and Solutions] In Naše selo [Our Village], edited by M. Stojadinović, 560-567. Savremena opština.

Šućur, Z. 2003. "Razvoj socijalne pomoći i socijalne skrbi u Hrvatskoj nakon Drugog svjetskog rata" [The Development of Social Assistance and Social Care in Croatia after World War II]. Revija za socijalnu politiku10 (1): 1-22.

Szikra, D., and B. Tomka. 2009. "Social Policy in East Central Europe: Major Trends in the Twentieth Century." In Post-Communist Welfare Pathways: Theorizing Social Policy Transformations in Central and Eastern Europe, edited by Alfio Cerami and Pieter Vanhuysse, 17-34. Basingstoke: Palgrave Macmillan.

Torpe, L. 2003. "Social Capital in Denmark: A deviant case?” Scandinavian Political Studies 26: 27-48.

Vuković, D. 2013. "Social Economy, Civil Society and the Serbian Welfare System." In Cooperatives and Social Enterprises in Europe and in Transitional Contexts, edited by S. Cvejić, 62-79. Belgrade: The Sociological Association of Serbia and Montenegro and the Institute for Sociological Research.

Vuković, D. and N. Perišić. 2011. "Social Security in Serbia - Twenty Years Later." In Welfare States in Transition-20 Years after the Yugoslav Welfare Model, edited by M. Stambolieva and Stefan Dehnert, 165-202. Sofia: Friedrich Ebert Foundation. 